\title{
REVIEW
}

\section{New methods of treatment in an experimental murine model of systemic lupus erythematosus induced by idiotypic manipulation}

Yehuda Shoenfeld, Ilan Krause, Miri Blank

The survival of patients with systemic lupus erythematosus (SLE) has improved tremendously over the past several decades, from a two year survival of $50 \%$ in $1939^{1}$ to five and 10 year survival of $90 \%$ and $80 \%$ respectively in the $1980 \mathrm{s.}^{2}$ This improvement is attributed mainly to the availability of dialysis, use of corticosteroids and cytotoxic drugs, and improved antibiotics and antihypertensive agents. However, since the introduction of cytotoxic agents in the treatment of severe SLE, no significant breakthrough in the treatment of lupus patients has been reported. This is probably because the aetiology of the disease is still unknown, and because of the great diversity of the clinical expressions of the disease-which makes it difficult to assess the effect of novel treatments - and the long follow up needed to evaluate changes in prognosis. Moreover, since $80-90 \%$ of lupus patients are young women, the use of experimental treatments which might decrease fertility, increase teratogenesis, or have other undesirable side effects is greatly curtailed. Because of these limitations, animal models of SLE could be of considerable value in the evaluation of novel and experimental treatments which that cannot be tested directly on patients. Various animal models of human SLE have been described, which tend to reflect different aspects of the disease. The prototype murine model of spontaneous SLE is the New Zealand black (NZB) mouse, ${ }^{3}$ principally a model of autoimmune haemolytic anaemia, accompanied by kidney disease and autoantibodies against erythrocytes, ssDNA and dsDNA. A hybrid strain derived from the NZB mouse is one produced by mating this strain with the New Zealand white mouse, the offspring being known as $(\mathrm{NZB} \times \mathrm{NZW}) \mathrm{F}_{1}{ }^{3}$ The $\mathrm{MRL} / \mathrm{lpr}$ mouse strain is a model for an accelerated membranoproliferative glomerulo-nephritis associated with anti-DNA production. ${ }^{4}$ Additional clinical features include lymphoproliferation, synovitis, and vasculitis. Another mouse model for SLE is the $\mathrm{B} \times \mathrm{SB}$ mouse, which is unusual in that the male develops autoimmunity earlier and in a more severe way than the female. Graft versus host disease (GVHD) is produced in mice by injecting lymphocytes from a parent into an $\mathrm{F}_{1}$ hybrid differing at one MHC locus from that parent. ${ }^{5}$ Several IgG autoantibodies are made, including anti-dsDNA and anti-histones, and fatal lupus-like nephritis mediated by IgG antiDNA occurs.

Most of the animal models for SLE described so far-except for GVHD-are genetically determined; hence the ability to manipulate the natural history of the disease or to examine the effect of treatments in different stages of the disease is limited. A few years ago, we introduced a novel method for induction of experimental autoimmune conditions, ${ }^{6-9}$ including SLE, involving idiotypic immunisation in naive mice. This method is based on Jerne's theory, ${ }^{10}{ }^{11}$ in which the idiotypic determinant of each autoantibody is complemented by those of another, creating an idiotypic network through which immunoglobulin expression might be controlled. This is manifested by the generation of anti-idiotypic antibodies $(\mathrm{Ab})$ of two functional subsets: those that recognise determinants in the $\mathrm{V}$ region and do not involve the combining site for the elicit antigen, and those that represent internal images of the elicit antigen (fig 1). We found that immunisation of naive mice in the footpads with a specific autoantibody (for example, anti-dsDNA, anti-cardiolipin, or anti-proteinase- 3 antibodies) emulsified in Freund's adjuvant, followed by a boost injection three weeks later, led to the generation of $\mathrm{Ab}_{2}$, namely an antiautoantibody, and later to mouse $\mathrm{Ab}_{3}$ (anti-anti-autoantibody), which simulates the original autoantibody (human or mouse origin) (fig 1). This ends with naive mice producing specific pathogenic autoantibodies, followed by the emergence of the full blown serological, immunohistochemical, and clinical manifestations of the respective autoimmune disease. In a series of experiments we and others have shown that immunisation of various strains of mice with monoclonal ${ }^{913}$ or polyclonal $^{14}$ human $^{12-15}$ or mouse ${ }^{15}$ anti-DNA antibody, carrying mainly the pathogenic $16 / 6$ Id, ended in the production of a panoply of
Accepted for publication 20 September 1996 
SLE related autoantibodies by the mouse (anti-DNA, anti-Sm, anti-Ro, anti-histones), a phenomenon referred by us as "autoantibody spread" ${ }^{16}$ The serological markers were associated with typical clinical findings of SLE such as increased erythrocyte sedimentation rate (ESR), leucopenia, thrombocytopenia, proteinuria, alopecia, and paralysis, as well as deposition of the mouse anti-DNA antibodies in the glomeruli of the kidneys, skin, and brain $^{89_{12-17}}$ (fig 2). The time interval between immunisation with $A b_{1}$ and generation of mouse $\mathrm{Ab}_{3}$, and autoimmune manifestations, is probably related to many factors, such as genetic predisposition in certain mice strains, the mode of immunisation, and the pathogenic potential of $A b_{1}$. We found that BALB/c mice immunised with pathogenic anti-DNA antibodies develop mouse $\mathrm{Ab}_{3}$ 2-3 months after immunisation, and full autoimmune disease after four to six months.

We postulate that the natural analogy of this experimental model in humans resides in the induction of antibacterial antibodies carrying pathogenic idiotypes. Indeed, we have already reported previously on the presence of increased titres of the $16 / 6 \mathrm{Id}$ in the sera of patients infected with mycobacteria (pulmonary tuberculosis) ${ }^{18}$ and klebsiella (pneumonia and urinary tract infections) or other Gram negative bacteria. ${ }^{19}$ Thus it is conceivable that infection may trigger autoimmune diseases by inducing antibacterial antibodies carrying the pathogenic idiotypes of autoantibodies $\left(\mathrm{Ab}_{1}\right)$. In the presence of adjuvant effect (or superantigen?) attributed to the various bacteria themselves, these antibodies may start-in a subject with the "proper" histocompatibility antigens and hormonal background - the cascade of idiotypic dysregulation shown by us in the experimental models, leading eventually to the generation of $\mathrm{Ab}_{3}$ (autoantibody spread), which, either by itself or through regulation, may lead to the overt

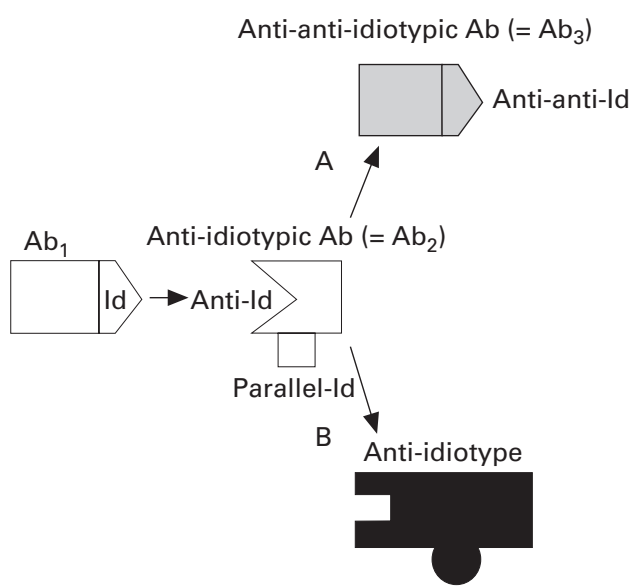

Figure 1 The idiotypic network according to ferne's theory: immunisation with the $A g(A b)$ leads to generation of anti-idiotypic $\mathrm{Ab}\left(\mathrm{Ab} \mathrm{b}_{2}\right)$ against the antigen binding site (variable region) of $A b_{1}$. A $b_{2}$ also has idiotypes outside its binding site (parallel Id). The idiotypes of $A b_{2}$ are recognised by the immune system to generate the $A b_{3}$ (anti-anti-Id) which resemble the structure of $A b_{1}(A)$. Alternatively, $A b_{3}$ may be generated against idiotype residing outside the binding site $(B)$, and may function as a regulatory anti-Id, without similarity to the original $\mathrm{Ag}$. clinical autoimmune condition (fig 3). Employing this model, we and others have tested the efficacy of several modes of treatments, in different stages of the disease. In this review we summarise the experience with those treatments, with their potential implications to patients with SLE.

\section{Hormonal manipulations}

The strongest risk factor for the development of SLE is female gender. It was felt, therefore, that study of sex related factors would offer a clue to the pathogenesis and treatment of SLE. Studies in the NZB/W $F_{1}$ murine model for SLE supported a role for female hormones in the modulation of autoantibody production and development of renal disease and death. ${ }^{20}$ Human studies for the effect of sex hormones in SLE patients are limited, and the results have been conflicting. ${ }^{2122}$ We studied the effect of sex hormones upon the induction of experimental SLE in BALB/c female and male mice which underwent orchiectomy. ${ }^{23}$ It was found that injection of the pathogenic idiotype to females, and to orchiectomised male mice, caused a rapid outburst of the disease compared to non-oestrogen-treated mice. Testosterone treated mice developed the usual response to the human anti-DNA antibody, but failed to develop fulminant SLE-like disease. In another study, the effect of tamoxifen, a synthetic non-steroidal antioestrogen compound, on the development and course of the disease in lupus mice was examined. ${ }^{24}$ Although tamoxifen treatment had no effect on the 16/6 Id induced antibody production, it cured the clinical manifestations of the disease. It is noteworthy that delayed tamoxifen treatment also had beneficial therapeutic effects, although it was not as effective as early treatment. ${ }^{24}$ The results point to the importance of sex hormones in the pathogenesis of SLE, and to the possible beneficial effects of androgen or anti-oestrogen treatment in early stages of the disease. During the last years, not much research has been done in developing new hormonal treatments for SLE patients. Treatment of limited number of patients with the androgen metabolite nandrolene resulted in improvement of disease manifestations in women, but men got worse. ${ }^{21}$ However, in another study this drug was ineffective in SLE patients. ${ }^{22}$ Until now, only danazol - an attenuated male sex hormonehas been shown to be of some value in treating haematological (thrombocytopenia) and skin manifestations of SLE. ${ }^{25}{ }^{26}$ We believe that our results might promote further research to establish the potential of hormonal modulation of the disease in lupus patients.

Prolactin, as a sex hormone, has been found to affect the immune response and modify the expression of autoimmunity in animals and humans. ${ }^{27}$ Bromocriptine, a dopamine agonist, suppresses the secretion of prolactin by the pituitary gland and in human and animal studies has been found to have immunoregulatory properties. ${ }^{27}{ }^{28}$ Evaluating the effect of bromocriptine treatment on mice with experimental 


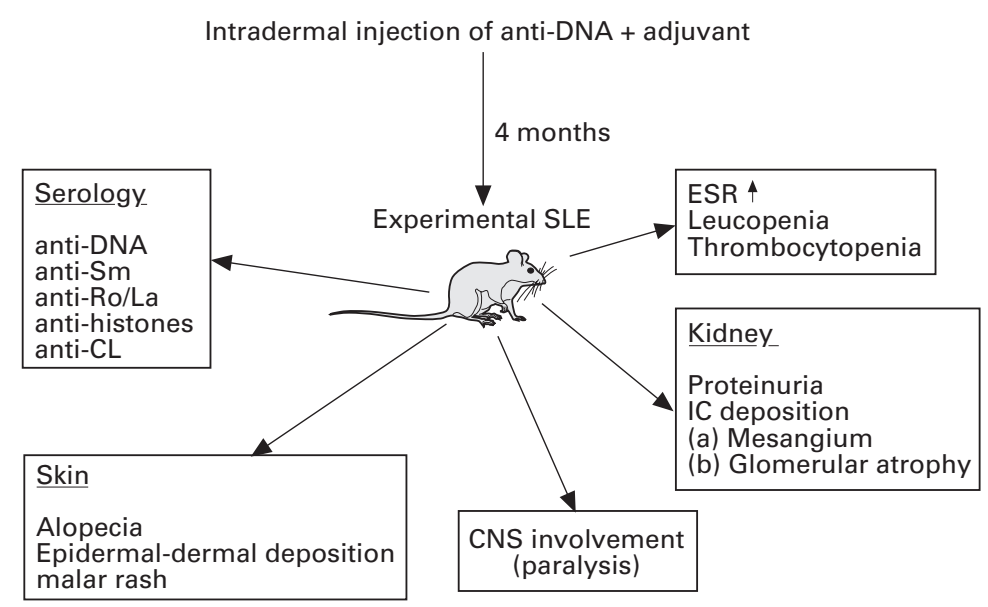

Figure 2 Manifestations of experimental SLE induced in naive mice by immunisation with pathogenic idiotypes of anti-DNA antibodies.

SLE, ${ }^{29}$ we observed a marked reduction of autoantibody levels accompanied by disappearance of clinical and pathological manifestations of the disease. The effect of bromocriptine seems to be non-specific for SLE, since a similar effect was observed in mice with experimental antiphospholipid syndrome (APS). ${ }^{29}$ Those results were supported by in vitro non-specific effect of CD8 cells, induced in vivo by bromocriptine, on specific lymph node cell proliferation in the presence of pathogenic and non-pathogenic autoantibodies. We also found that injection of CD8 cells from bromocriptine treated mice with SLE or APS abolished the development of disease in the SLE and APS models. Our findings suggest a possible role for bromocriptine in downregulating autoimmune phenomena through induction of natural non-specific CD8 suppressor cells. The effect of bromocriptine treatment in SLE patients has not been tested in controlled trials, but a few published case reports imply a beneficial effect. ${ }^{30}$ Recently, it has been reported that SLE patients treated with bromocriptine for six to nine months had a significant decrease in disease activity, associ-

Idiotypic induction of autoimmune diseases

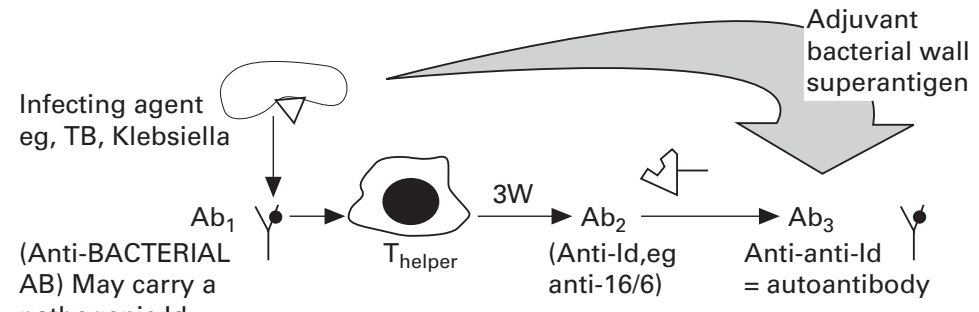
pathogenic Id

$($ eg, $16 / 6$ Id)

$\begin{array}{ll}\text { Healthy subject } & \text { Autoimmune } \\ \text { >Male } & \text { disease } \\ \text { HLA-DR6 } & >\text { Female } \\ \mathrm{N}-\lg \text { A } & \text { HLA DR 2,3,4 } \\ \mathrm{N}-\mathrm{C}^{\prime} & \text { C2,C4 deficient }\end{array}$

Figure 3 Autoimmunity triggered by infection: an ineffective agent induces antibacterial antibody $\left(A b_{1}\right)$ carrying a pathogenic idiotype. Following the generation of anti-idiotypic antibody $\left(\mathrm{Ab}_{2}\right)$ and anti-anti-idiotypic antibody $\left(A b_{3}\right)$, which is the pathogenic autoantibody, and in the "proper" conditions (for example, HLA antigens, hormonal background, immune dysregulation) autoimmune disease may be induced. ated with lower titres of anti-dsDNA antibodies. ${ }^{31}$ Our results are in line with those reports, and may suggest a clinical application of bromocriptine treatment in SLE patients.

\section{Immunomodulation}

Several immunomodulations have been tried in an attempt to manipulate the course and outcome of mice with experimental SLE induced by idiotypic immunisation. These include anti-idiotypic or anti-CD4 antibodies, idiotype specific $\mathrm{T}$ suppressor cells, intravenous immunoglobulins, treatment with several cytokines, or an attempt to induce oral tolerance to the pathogenic idiotype.

ANTI-IDIOTYPIC MODULATION

Since the idiotypic network is an important mechanism controlling the immune repertoire, ${ }^{10}$ and autoimmune diseases may be attributed to disturbance of the network, ${ }^{32}$ several groups have employed an anti-idiotypic modulation in experimental models. Indeed, successful in vitro and in vivo manipulations of autoantibodies production by anti-idiotypic antibodies have been reported in several animal models for autoimmune diseases. ${ }^{33-35}$ Enhancement of the effect of anti-idiotypic antibodies was also tried by conjugation with cytotoxic agents, one of which was saporin. ${ }^{36}$ On the basis of those studies, we manipulated mice with experimental SLE with an anti-16/6 Id monoclonal antibody conjugated to saporin. ${ }^{37}$ We observed a significant reduction in the titres of serum autoantibodies, with diminished clinical manifestations. Those effects were obtained using anti-Id monoclonal antibody, and were even more remarkable when the immunotoxin anti-Id monoclonal antibody-saporin conjugate was employed. These suppressive effects were specific, since this treatment had no effect upon mice with experimental APS. ${ }^{37}$ The anti-Id effect was mediated through a reduction in specific anti-DNA antibody forming cells, and lasted as long as the anti-Id injections were given. These results add further support to the importance of pathogenic idiotypes in SLE, pointing to the potential effectiveness of anti-idiotypic treatment in SLE patients. Since, however, a growing number of pathogenic idiotypes has already been identified in SLE, ${ }^{38}$ a combination ("cocktail") of anti-idiotypic antibodies might be necessary for an effective treatment.

MONOCLONAL ANTIBODIES AGAINST CD4 MOLECULES

The CD4 molecule is a glycoprotein coreceptor of the antigen receptor on $\mathrm{T}$ cells, the main functions of which are binding to major histocompatibility complex (MHC) molecules and guiding $\mathrm{T}$ cells toward class II MHC recognition. ${ }^{39}$ Monoclonal antibodies against CD 4 molecules can block $T$ cell activation and proliferation and the release of cytokines. ${ }^{40}$ Indeed, immunotherapy with antiCD4 antibodies has been shown to suppress autoimmunity in several animal models of 
autoimmune diseases, and in some human autoimmune conditions. ${ }^{4142}$ We have found that CD4+ $\mathrm{T}$ cells play a central role in the pathogenesis of experimental SLE: injection of CD4+ T cells specific for the $16 / 6$ Id into naive $\mathrm{BALB} / \mathrm{c}$ mice resulted in the typical serological and clinical manifestations of experimental SLE. ${ }^{43}$ Following these results, we examined the ability of anti-CD4 antibodies to prevent or to treat experimental SLE. ${ }^{44}$ We treated the mice with rat anti-CD4 monoclonal antibody, either before disease induction or when the mice had already developed serological but not clinical signs of the disease. Mice which were treated with anti-CD4 monoclonal antibody developed significantly lower levels of autoantibodies, and lacked the clinical manifestations of SLE. It seems therefore that anti-CD4 treatment is particularly effective in early stages of the disease, when only the serological markers of the disease are present.

SPECIFIC T SUPPRESSOR TO THE PATHOGENIC AUTOANTIBODY

$\mathrm{T}$ Suppressor ( $\mathrm{Ts}$ ) activity is an important immunoregulatory mechanisms, controlling autoantibody production in B lymphocytes. Several publications have reported decreased number and activity of Ts cells in mouse models for SLE, ${ }^{45}$ and SLE patients. ${ }^{46}$ If the production of autoantibodies in SLE is related to downregulation of Ts cells, then reconstitution of Ts cell number and activity, especially the Ts specific to the pathogenic autoantibody, may lead to amelioration of disease manifestations. Indeed, previously a few studies have confirmed this assumption. ${ }^{47} 48$ To study the role of $\mathrm{T}$ cells and pathogenic idiotypes in SLE, we have established Ts cells specific for anti-DNA idiotype 16/6. These Ts cells were generated from $B A L B / c$ enriched $T$ cells exposed in vitro to the pathogenic $16 / 6 \mathrm{Id} .{ }^{49} \mathrm{We}$ found that weekly intravenous injections of 16/6 Id specific Ts cells, given to SLE mice at different stages of the disease, prevented the clinical and serological manifestations. It should be emphasised, however, that this treatment failed once the disease was well established. The results of this study support the notion of the role of pathogenic idiotypes in murine SLE, and the role Ts cells may take in induction as well as in modulation of autoimmune conditions.

HUMAN IMMUNOGLOBULIN GIVEN INTRAVENOUSLY

Normal human immunoglobulin given intravenously (IVIG) has been reported to be effective in treating several autoimmune diseases. ${ }^{50}$ Several recently published case reports imply that IVIG may have beneficial effect upon various expressions of SLE. ${ }^{51-54}$ The advantages of IVIG treatment are considerable because of to its infrequent side effects and lack of immunosuppression. The precise mechanism of action of IVIG in autoimmunity is not yet clear, but much of its immunomodulation is attributed to manipulation of the idiotypic network. ${ }^{50}$ We evaluated the effect of IVIG treatment on immunological and clinical findings in mice with experimental $\mathrm{SLE}^{55}$ which were treated with IVIG (whole molecule, $\mathrm{F}(\mathrm{ab})_{2}$ or Fc fragments). SLE mice, treated with IVIG or its $\mathrm{F}(\mathrm{ab})_{2}$ fragments - but not the $\mathrm{Fc}$ fragmenthad a complete clinical, serological, and pathological remission which lasted as long as the treatment was given. Inhibition studies pointed to the presence of anti-idiotypic activity to anti-dsDNA antibodies in the IVIG preparation. ${ }^{55}$ This implies that the therapeutic effect of the IVIG treatment in our model might be mediated through manipulation of the idiotypic network and neutralisation of pathogenic autoantibodies. The findings are in line with previous studies that show the presence of anti-idiotypic activity in IVIG preparations to several autoantibodies associated with autoimmune diseases. ${ }^{56-58}$ This may raise the possibility of analysing patients' serum with the specific IVIG batch before treatment, in analogy to bacterial sensitivities to various antibiotics. Our results further strengthen the role of IVIG treatment in SLE, and may promote the handling of controlled clinical trials in this expensive, yet apparently effective, treatment.

SYNTHETIC IMMUNOMODULATOR AS101

The CD4+ cells are now recognised as having two subsets-Th1 and Th2-based on their cytokine secretion. Th1 clones produce interleukin-2 (IL-2), interferon (IFN- $\gamma$ ), and tumour necrosis factor (TNF), and are the principle effectors of delayed type hypersensitivity reactions. Th2 cells produce IL- 4 , IL-5, IL-10, and IL-13, stimulate IgE and IgG1 antibody production, and inhibit macrophage function. ${ }^{59}$ Prevalent Th2 response seems to be involved in the immunopathogenesis of SLE, since a major abnormality of the immune system in SLE is the T cell dependent B cell hyperactivity, and impaired cell mediated immunity. ${ }^{60}$ Moreover, a Th2-type immune response has been clearly shown to be pathogenic in experimental SLE induced by allogeneic stimulation or chemicals. ${ }^{61}$ There have also been reports of a decrease in the production of IL-2 in autoimmune mice and humans. ${ }^{6263}$ In preliminary results, we noticed that the production of IL-2 is reduced in mice with experimental SLE. This led us to consider treatment of those mice with the synthetic immunomodulator AS101, which has been found to have a potential therapeutic effect on various immune mediated conditions, attributed to its ability to increase the production of IL-2 and colony stimulating factor in vivo and in vitro. ${ }^{64}$ We found that splenocytes from the SLE mice had a significant decrease in the ability to secrete IL-2. Treatment of the mice with AS101 restored the ability of the splenocytes to secrete IL-2 to normal levels. The treatment, however, had no effect on clinical or serological indices of SLE. ${ }^{65}$ In another study, mice were treated with IFN- $\gamma$ before disease induction. It was found that those mice 
Table 1 The effect of various experimental treatments on mice with experimental SLE

\begin{tabular}{|c|c|c|c|}
\hline Treatment & Rationale for treatment & Study protocol & Effect on experimental SLE \\
\hline Sex hormones ${ }^{2324}$ & $\begin{array}{l}\text { Sex hormones may play a role in the } \\
\text { pathogenesis of SLE, since females are } \\
\text { much more prone to develop SLE }\end{array}$ & $\begin{array}{l}\text { The hormones were implanted subcutaneously, to } \\
\text { achieve constant levels. One week later, the mice were } \\
\text { immunised with the } 16 / 6 \text { Id }\end{array}$ & $\begin{array}{l}\text { Testosterone and tamoxifen } \\
\text { attenuated, while oestrogen } \\
\text { aggravated SLE expression }\end{array}$ \\
\hline $\begin{array}{l}\text { Bromocriptine } \\
\quad(\text { BRC })^{29}\end{array}$ & $\begin{array}{l}\text { Prolactin (PRL) enhances the expression } \\
\text { of autoimmunity in humans and animals, } \\
\text { BRC supresses PRL secretion }\end{array}$ & $\begin{array}{l}\text { Immunised mice were treated with IP BRC for } 6 \text { weeks, } \\
\text { starting } 2 \text { months after disease induction (ie, early } \\
\text { disease stage) }\end{array}$ & $\begin{array}{l}\text { Complete serological, histological, } \\
\text { and clinical remission }\end{array}$ \\
\hline Cytokines $^{65}$ & $\begin{array}{l}\text { Th2 cells are important in the } \\
\text { immunopathogenesis of experimental } \\
\text { SLE.. Role of Th1 cells unclear }\end{array}$ & $\begin{array}{l}\text { Immunised mice were treated with AS101 (increases the } \\
\text { production of IL-2), IP for } 7 \text { weeks, or with INF- } \gamma \text {, } \\
\text { before disease induction }\end{array}$ & $\begin{array}{l}\text { No effect of IL- } 2 \text {. INF- } \gamma \text { caused } \\
\text { rapid outburst of the disease, with } \\
\text { raised IL- } 4 \text { and IL- } 6\end{array}$ \\
\hline $\begin{array}{l}\text { Anti-idiotypic } \\
\text { antibodies }^{37}\end{array}$ & $\begin{array}{l}\text { Autoimmune diseases may result from } \\
\text { dysregulated idiotypic network }\end{array}$ & $\begin{array}{l}\text { Immunised mice were treated, } 2 \text { months after disease } \\
\text { induction, with anti-16/6 Id Sb by daily IP injections for } \\
1 \text { month }\end{array}$ & $\begin{array}{l}\text { Attenuation of disease } \\
\text { manifestations, mediated through } \\
\text { reduction of anti-DNA Ab forming } \\
\text { cells }\end{array}$ \\
\hline Id-specific Ts cells ${ }^{49}$ & $\begin{array}{l}\text { Production of autoantibodies in SLE may } \\
\text { be ralated to downregulation of Ts cells }\end{array}$ & $\begin{array}{l}\text { SLE mice were treated, at different stages of the disease, } \\
\text { with weekly IV injections of } 16 / 6 \text { Id-specific Ts cells, for } \\
8 \text { weeks }\end{array}$ & $\begin{array}{l}\text { Early treatment prevented disease } \\
\text { manifestations, treatment at late } \\
\text { disease stage was less effective }\end{array}$ \\
\hline $\begin{array}{l}\text { Anti-CD4 } \\
\quad \text { antibodies }^{47}\end{array}$ & $\begin{array}{l}\text { Anti-CD4 Abs can block } \mathrm{T} \text { cell activation, } \\
\text { proliferation and release of cytokines, and } \\
\text { suppress autoimmunity }\end{array}$ & $\begin{array}{l}\text { SLE mice were treated with rat anti-CD } 4 \mathrm{mAb} \text {, either } \\
\text { before and during disease induction, or } 2 \text { months after } \\
\text { disease induction }\end{array}$ & $\begin{array}{l}\text { Prevention of clinical manifestations, } \\
\text { especially in early stages of the } \\
\text { disease }\end{array}$ \\
\hline $\mathrm{IVIG}^{55}$ & $\begin{array}{l}\text { IVIG treatment was found effective in } \\
\text { several autoimmune diseases, including } \\
\text { case reports on SLE }\end{array}$ & $\begin{array}{l}\text { SLE mice were treated with IVIG (whole molecule, } \\
\mathrm{F}(\mathrm{ab})_{2} \text { or Fc fragments), starting } 2 \text { months after disease } \\
\text { induction, for } 6 \text { weeks }\end{array}$ & $\begin{array}{l}\text { Complete remission, probably } \\
\text { mediated by anti-idiotypic activity }\end{array}$ \\
\hline Oral tolerance & $\begin{array}{l}\text { Systemic tolerance can be achieved by } \\
\text { feeding with pathogenic proteins }\end{array}$ & $\begin{array}{l}\text { Mice were given different doses of the } 16 / 6 \text { Id }(10-1000 \\
\mu \mathrm{g}) \text { by oral intubation, } 3 \text { times every } 3 \text { days, before } \\
\text { immunisation with the pathogenic Id }\end{array}$ & $\begin{array}{l}\text { Different doses of oral } 16 / 6 \text { Id did } \\
\text { not change disease expression }\end{array}$ \\
\hline
\end{tabular}

developed earlier and more sever disease, accompanied by raised concentrations of IL- 4 and IL-6. These results points to the importance of Th1 as well as Th2 in the immunopathogenesis of SLE in our model.

SYSTEMIC TOLERANCE

Systemic tolerance to various antigens can be achieved by feeding with pathogenic proteins. ${ }^{66}$ It has been found that oral administration of autoantigens suppresses disease development in animal models of autoimmunity. ${ }^{67}$ Nevertheless, immune responsiveness can also be enhanced by antigens presented to, and absorbed through, the intestine. ${ }^{68}$ Strains of lupus mice $(\mathrm{B} \times \mathrm{SB}, \mathrm{MRL} / \mathrm{lpr}$, and $\mathrm{NZB})$ differed in their capacity to become orally tolerised after feeding with bovine $\gamma$ globulin and casein. ${ }^{6970}$ The mechanisms of tolerance in lupus-prone mice seem to be affected by multiple factors not present in normal strains of mice, and the reasons for such a difference

$\uparrow$ Increased manifestations $\checkmark$ Decreased manifestations $\varnothing$ No influence

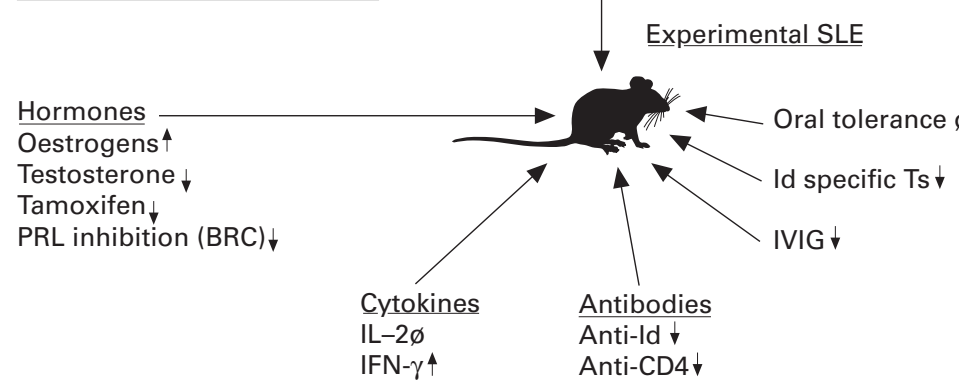

Figure 4 Effect of various experimental treatments on mice with experimental SLE (see also the table). between lupus-prone and normal mice remain unclear. ${ }^{71}$ In an attempt to establish antigen specific unresponsiveness in the experimental SLE model, mice were given different doses of anti-DNA (16/6 Id+) antibody, by oral intubation, after which they were immunised with the $16 / 6$ Id. A significant increment in the level of anti-16/6 Id and anti-DNA antibody titres was detected in the sera of the 16/6 Id orally treated mice in comparison with the control groups, while the clinical indices of the disease remained the same. Hence, it was found that oral feeding of $16 / 6 \mathrm{Id}$ did not induce tolerance, and might even induce priming of the disease.

\section{Summary}

In this article we have presented our experiences and those of others with various experimental and novel treatments in an experimental model of murine SLE, induced by immunisation with pathogenic anti-DNA antibody (fig 4). Many of the treatments (summarised in the table) were highly effective in ameliorating clinical, serological, and histological manifestations of the disease. According to our results, it seems that hormonal treatments - such as testosterone metabolites, anti-oestrogens, or bromocriptine-as well as immunomodulation with IVIG or anti-CD4 antibodies, hold the most promising potential for application in lupus patients. We believe, therefore, that these types of treatment should receive high priority in human trials. It should be emphasised, however, that the timing of treatment may be critical, since several treatments were effective when used before or during the induction of the disease. This limitation may pose difficulty for human application, since the aetiology of SLE is still obscure and is probably multifactorial ${ }^{38}$; therefore it is not yet possible to identify patients at risk of developing SLE. Nevertheless, those treatments which proved to be effective might be used early in the course of the disease in 
lupus patients and hence influence the outcome of the disease, or may even induce partial or complete remission.

Supported by the Felix and Ruta Zandman fund for research in autoimmune diseases.

1 Pickering G, Bywaters EGL, Damielli JF, Gell PG, Kellgren $\mathrm{JH}$. Treatment of systemic lupus erythematosus with steroids. Report to the Medical research Council by the
Collagen Diseases and Hypersensitivity Panel. BMJ Collagen Diseas

2 Ginzler EM, Diamond HS, Weiner M, Schlesinger M, Fries JF. A multi center study of outcome of systemic lupus erythematosus. I. Entry variables as

3 Theofilopoulus AN, Dixon FJ. Murine models of systemic lupus erythematosus. Adv Immunol 1985;37:269-90.

4 Gutierrez-Ramos JC, Andreu JL, Moreno De Alboran I. Insights into autoimmunity: from classical models to current perspectives. Immunol Rev 1990;118:73-101.

5 Portanova JP, Ebling FM, Hammond WS, Hahn BH, Kotzin BL. Allogeneic MHC antigen requirements for lupus-like autoantibody production and nephritis in murine graft-vs-host disease. J Immunol 1988; 141:3370-6.

6 Bakimer R, Fishman P, Blank M, Sredni B, Djaldetti M, Shoenfeld Y. Induction of primary anti-phospholipid syndrome in mice by immunization with human monoclonal anti-cardiolipin antibody (H-3). J Clin Invest 1992; 89:1558-63.

7 Blank M, Tomer Y, Stein M, Kopolovic J, Wiik A, Meron PL, et al. Immunization with anti-neutrophil cytoplasmic
antibody (ANCA) induces the production of mouse antibody (ANCA) induces the production of mouse ANCA and perivascular lym

8 Shoenfeld Y. Idiotypic induction of autoimmunity: a new aspect of the idiotypic network. FASEB J 1994;8:1296301

9 Mendlovic S, Brocke S, Fricke H, Shoenfeld Y, Bakimer R, Mozes E. The genetic regulation of the induction of experimental SLE. Immunology 1990;69:228-36.

10 Jerne NK. Toward a network theory of the immune system. Ann Immunol 1974;125:373-89.

11 Jerne NK, Roland J, Cazenava PA. Recurrent idiotypes and internal images. EMBO J 1982;1:243-7.

12 Mendlovic S, Brocke S, Shoenfeld Y, Ben-Bassat M, Meshorer A, Bakimer R, et al. Induction of a systemic lupus erythematosus-like disease in mice by a common human anti-DNA idiotype. Proc Natl Acad Sci USA 1988;85:2260-4.

13 Blank M, Mendelovic S, Mozes E, Shoenfeld Y. Induction of SLE like disease in naive mice with a monoclonal anti-DNA antibody derived from a patient with polymyositis carrying 16/6 Id. J Autoimmunity 1988;1:683-9.

14 Tincani A, Balesterieri G, Allegri F, Cattaneo R, Fornasieri $\mathrm{A}$, Sinico $\mathrm{A}$, et al. Induction of experimental SLE in naive mice by immunization with human polyclonal anti-DNA antibody carrying

15 Blank M, Krup M, Mendelovic S, Ericke H, Mozes E, Talal $\mathrm{N}$, et al. The importance of the pathogenic $16 / 6$ idiotype in the induction of SLE in naive mice. Scand J Immunol 1990;31:45-52.

16 Shoenfeld Y, Mozes E. Pathogenic idiotypes of antibodies and autoimmunity: lessons from new experimental models of SLE. FASEB J 1990;4:2646-51.

17 Rombach E, Stetler DA, Brown JC. Rabbits produce SLE-like anti-RNA polymerase I and anti-DNA autoantibodies in response to immunization with either human or bodies in response to immunization with either human or
murine SLE anti-DNA antibodies. Autoimmunity 1992; murine SLE

18 Sela O, El-Roeiy A, Isenberg DA, Kennedy RL, Colaco CB, Pinkhas J, et al. A common anti-DNA antibody idiotype in sera of patients with active pulmonary tuberculosis Arthritis Rheum 1987;30:50-5

19 El-Roeiy A, Sela O, Isenberg DA, Kennedy RL, Shoenfeld $\mathrm{Y}$. The sera of patients with klebsiella infections contain a common anti-DNA idiotype (16/6 Id) anti-polynucleotide activity. Clin Exp Immunol 1987;67:507-15.

20 Rubinian JR, Talal N, Greenspan JS, Goodman JR, Siiteri PK. Effect of castration and sex hormones treatment on PK. Effect of castration and sex hormones treatment on
survival, anti-nucleic acid antibodies and glomerulonesurvival, anti-nucleic acid antibodies and glomerulone-
phritis in NZB/NZW F1 mice. J Exp Med 1978; phritis in NZB $14768-83$.

21 Lahita RG, Kunkel HG. Treatment of systemic lupus erythematosus (SLE) with the androgen 19-nortestosterone (Nandrolone) [abstr]. Arthritis Rheum 1984 27(suppl):S65

22 Hazelton RA, McCruden AB, Sturrock RD, Stimson WH Hormonal manipulation of the immune response in systemic lupus erythematosus: a drug trial of an anabolic steroid, 19-nortestosterone. Ann Rheum Dis 1983; 42:155-7.

23 Blank M, Mendlovic S, Fricke H, Mozes E, Talal N Shoenfeld Y. Sex hormone involvement in the induction of experimental systemic lupus erythematosus by a pathogenic anti-DNA idiotype in naive mice. J Rheumato 1990;17:311-7.
24 Sthoeger ZM, Bentwich Z, Zinger H, Mozes E. The beneficial effect of the estrogen antagonist, tamoxifen, on experimental systemic lupus erythematosus. J Rheumatol 1994; 21:2231-8.

25 Chan AC, Sack K. Danazol therapy for autoimmune hemolytic anemia associated with systemic lupus erythematosus [case report]. J Rheumatol 1991;18:280-2.

26 Aranegui P, Giner P, Lopez-Gomez M, el-Amrani A, Jimenez-Alonso J. Danazol for Evans syndrome due to SLE. Drug Intell Clin Pharmacol 1990;24:641-42.

27 Buskila D, Sukenic S, Shoenfeld Y. The possible role of prolactin in autoimmunity. Am J Reprod Immunol 1991; 26:118-23.

28 Whyte A, Williams RO. Bromocriptine suppresses postpartum exacerbation of collagen-induced arthritis. Arthritis Rheum 1988;31:927-8.

29 Blank M, Krause I, Buskila D, Teitelbaum D, Kopolovic J, Afek A, et al. Bromocriptine immunomodulation of experimental SLE and primary anti-phospholipid syn-
drome via induction of nonspecific T suppressor cells. Cell drome via induction of nonspeci

30 Rabinovich CE, Schanberg LE, Kredich DW. Intravenous immunoglobulin and bromocriptine in the treatment of refractory neuropsychiatric systemic lupus erythematosus [abstr]. Arthritis Rheum 1990;33:R22.

31 McMurray RW, Weidensaul D, Allen SH, Walker SE. Efficacy of bromocriptine in an open label therapeutic trial for systemic lupus erythematosus. J Rheumatol 1995; 11:2084-91

32 Burdette D, Schwarts RS. Idiotypes and idiotypic networks. N Engl J Med 1987;317:219-24.

33 Aguis MA, Richmann DP. Suppression of development of experimental autoimmune myasthenia gravis with isogenic monoclonal anti idiotypic antibody. J Immunol 1986; 137:2195-8.

34 Nordling C, Holmdahl R, Klareskog L. Down of collagen arthritis after in vitro treatment with syngenic monoclonal anti-idiotypic antibody to a cross reactive idiotype on col-
lagen II autoantibodies. Immunology 1991;72:486-92.

35 Zou SR, Whitaker JN. Specific modulation of T cells and murine experimental allergic encephalomyelitis by monoclonal anti-idiotypic antibodies. J Immunol 1993; 150:1629-42.

36 Mansoroi J, Von Kleist S, Mansoroi A, Grunert F. Thermostability and antitumor activity on colon cancer cell lines on monoclonal anti-CEA antibody-saporin cell lines on monoclonal anti-CEA antibody-

37 Blank M, Mansoroi J, Tomer Y, Mansoroi A, Kopolovic J, Charcon-Polak S, et al. Suppression of experimental systemic lupus erythematosus (SLE) with specific antiidiotypic antibody-saporin conjugate. Clin Exp Immunol 1994;98:434-41.

38 Shoenfeld Y, Isenberg DA. The mosaic of autoimmunity, the factors associated with autoimmune diseases. Amsterdam: Elsvier, 1989

39 Koing R, Huang LY, Germain RN. MHC class II interaction with $\mathrm{CD} 4$ mediated by a region analogous to the MHC class I binding site for CD8. Nature 1992; 356:796-8.

40 Benjamin RJ, Waldmann $\mathrm{H}$. Induction of tolerance by monoclonal antibody therapy. Nature 1986:320:449-51.

41 Riethmuller G, Rieber B, Kiefersauer S, Prinz J, van der Lubbe P, Meiser B, et al. From antilymphocyte serum to therapeutic monoclonal antibodies: first experiences with chimeric CD4 antibody in the treatment of autoimmune disease. Immunol Rev 1992;129:81-103.

42 Reiter C, Kakavand B, Rieber EP, Schattenkirchner M, Riethmuller G, Kruger K. Treatment of rheumatoid arthritis with monoclonal CD4 antibody M-T151: clinical results and immunopharmacologic effects in an open study, including repeated administration. Arthritis Rheum 1991;34:525-36.

43 Blank M, Mendlovic S, Mozes E, Coates ARM, Shoenfeld $\mathrm{Y}$. Induction of systemic lupus erythematosus in naive mice with T-cell lines specific for human anti-DNA antibody SA-1 (16/6 Id+) and for mouse tuberculosis antibody TB/68 (16/6 Id+). Clin Immunol Immunopathol 1991;60:471-83.

44 Tomer Y, Blank M, Shoenfeld Y. Suppression of experimental antiphospholipid syndrome and systemic lupus erythematosus in mice by anti-CD4 monoclonal antibodies. Arthritis Rheum 1994;37:1236-44.

45 Krakauker RS, Waldmann TA, Strober WJ. Loss of suppressor $\mathrm{T}$ cell in adult NZB/NZW mice. J Exp Med 1976;144:663-73.

46 Raziuddin S, Nur MA, Alwabel AA. Selective loss of the $\mathrm{CD} 4+$ inducers of suppressor $\mathrm{T}$ cell subsets $(\mathrm{ZH} 4+)$ in active systemic lupus erythematosus. J Rheumatol 1989; 16:1315-9.

47 Naiki MY, Imai T, Osawa Y. Establishement of a nucleoside-specific suppressor $\mathrm{T}$ cell line from SLE pron (NZB/NZW)F1 mice. J Immunol 1985;135:1080-5.

48 Ellerman KE, Powers JM, Brostoff SW. A suppressor T-lymphocyte cell line for autoimmune encephalomyelitis. Nature 1988;331:265-7

49 Blank M, Ben-Bassat M, Shoenfeld Y. Modulation of SLE induction in naive mice by specific $\mathrm{T}$ cells with suppressor activity to pathogenic anti-DNA idiotype. Cell Immunol 1991;137:474-86.

50 Dweyer JM. Manipulating the immune system with immune globulin. N Engl J Med 1992;326:107-16.

51 Maier WP, Gordon DS, Howard RF, Saleh MN, Miller SB, Lieberman JD, et al. Intravenous immunoglobulin therapy 
in systemic lupus erythematosus associated thrombocytopenia Arthritis Rheum 1990;33:1233-39.

52 Winder A, Molad Y, Ostfeld I, Kenet G, Pinkhas J, Sidi Y. Treatment of systemic lupus erythematosus by prolonged administration of high dose intravenous immunoglobulin report of two cases. J Rheumatol 1993;20:495-8.

53 Tomer Y, Shoenfeld Y. Successful treatment of psychosis secondary to SLE with high dose intravenous immunoglobulin. Clin Exp Rheumatol 1992;10:391-3.

54 Ben-Chetrit E, Putterman C, Naparstek Y. Lupus refractory pleural effusion: transient response to intravenous immupleural effusion: transient response to intra
noglobulins. J Rheumatol 1991;18:1635-7.

55 Krause I, Blank M, Kopolovic J, Afek A, Goldberg I, Tomer $\mathrm{Y}$, et al. Abrogation of experimental systemic lupus erythematosus and primary antiphospholipid syndrome with intravenous gamma globulin. J Rheumatol 1995
$6: 1068-74$.

56 Dietrich G, Kazatchkine MD. Normal immunoglobulin G (IgG) for therapeutic use (intravenous Ig) contain antiidiotypic specificities against an immunodominant, diseaseassociated, cross-reactive idiotype of human antithyroglobulin autoantibodies. J Clin Invest 1990;85:62025.

57 Rossi F, Jayne DR, Lockwood CM, Kazatchkine MD. Antiidiotypes against anti-neutrophil cytoplasmic antigen auto-antibodies in normal human polyspecific IgG for therapeutic use and in the remission sera of patients
with systemic vasculitis. Clin Exp Immunol 1991;83:298303 .

58 Evans MJ, Suenaga R, Abdou NI. Detection and purification of antiidiotypic antibodies against anti-DNA in intravenous immune globulin. J Clin Immunol 1991;11:291-5.

59 Romagnani S. Biology of human Th1 and Th2 cells. J Clin Immunol 1995;15:121-9.

60 Mills JA. Systemic lupus erythematosus. N Engl J Med 1994;330:1871-9.

61 Goldman M, Druet P, Gleichmann E. Th2 cells in systemic lupus erythematosus: insights from allogeneic diseases and lupus erythematosus: insights from allogeneic diseases and
chemically induced autoimmunity. Immunol Today 1991; 12:223-7.
62 Alcocer-Varela J, Alarcon-Segovia D. Decreased production of and response to interleukin-2 by cultured lymphocytes from patients with systemic

63 Wofsy D, Murphy ED, Roths JB, Dauphinee MJ, Kipper SP, Talal N. Deficient interleukin-2 activity in MRL/Mp and C57BL/6J mice bearing the lpr gene. J Exp Med1981; 154:1671-80.

64 Sredny B, Caspi RR, Klein A, Kalechman Y, Danziger Y, Ben-Yaakov $M$, et al. A new immunomodulating compound (AS101) with potential therapeutic application. Nature 1987;330:173-6.

65 Blank M, Seredni B, Albeck M, Mozes E, Shoenfeld Y. The effect of the immunomodulator agent AS101 on interleukin-2 production in systemic lupus erythematosus (SLE) induced in mice by a pathogenic anti-DNA antibody. Clin Exp Immunol 1990;79:443-7.

66 Mowat MA. The regulation of immune responses to dietary protein antigens. Immunol Today 1987;8:93.

67 Higgins PJ, Weiner HL. Suppression of experimental autoimmune encephalomyelitis by oral administration of autoimmune encephalomyelitis by oral administration of myelin basic prote

68 Vives J, Parks DE, Weigle WO. Immunologic unresponsiveness after gastric administration of human gamma globulin: antigen requirements and cellular parameters. J Immunol 1980;125:1811-6.

69 Carr RI, Tilley D, Forsyth S, Etheridge P, Sadi D. Failure of oral tolerance in (NZBxNZW) F1 mice is antigen specific and appears to parallel antibody pattern in human systemic lupus erythematosus (SLE). Clin Immunol Immunopathol 1987;42:298-310.

70 Miller ML, Cowdery JS, Laskin CA, Curtin MF, Steinberg AD. Heterogeneity of oral tolerance defects in autoimmune mice. Clin Immunol Immunopathol 1984;31:23140.

71 Weiner HL, Friedmann A, Miller A, Khoury SJ, Al-Sabbagh A, Santos L, et al. Oral tolerance: immunologic mechanisms and treatment of animal and human organ-specific autoimmune diseases by oral administration of autoantigens. Annu Rev Immunol 1994;12:809-37. 